\title{
Serum big endothelin-1 as a biomarker in oral squamous cell carcinoma patients: an analytical study
}

\author{
Pritam Kumar MANKAPURE, Suresh Ramchandra BARPANDE, Jyoti Dilip BHAVTHANKAR, Manda MANDALE
}

Government Dental College and Hospital, Department of Oral Pathology and Microbiology, Aurangabad, India.

Corresponding address: Pritam K. Mankapure, Assistant Professor - Department of Oral Pathology and Microbiology, Government Dental College and Hospital - Dhanvantari Nagar - Aurangabad 431001 - Maharashtra - India - Phone: +91-9011179100 - e-mail: pritammankapure@gmail.com

Submitted: April 8, 2015 - Modification: July, 30 - Accepted: August 11, 2015

\section{ABSTRACT}

$\mathrm{D}$ etection of abnormally elevated levels of molecules in patients with oral cancer may be useful in early diagnosis. These markers can be included in current Histopathology grading and in TNM staging systems of Oral Squamous Cell Carcinoma (OSCC) to make it more efficient. Several pro-angiogenic molecules have been assessed for the same reason. Endothelin-1 (ET-1) is a vasoactive peptide associated with the development and spread of many solid tumors, including Squamous Cell Carcinoma (SCC), but its utility in OSCC has not been confirmed. Objective: This study aims to evaluate the role of the serum big ET-1 as a biomarker of OSCC, by correlating it with the clinical staging and the histopathological grading. Material and Methods: Serum levels of big ET-1 measured by the sandwich EnzymeLinked Immunosorbent Assay (ELISA) in 40 OSCC cases were compared with the levels from the control group using independent t-test. Clinical stages and histopathological grades of OSCC cases were compared in relation to their mean levels of serum big ET-1, one using the Analysis of Variance (ANOVA) test and the other the independent t-test, respectively. The significance of the mean difference between the groups was evaluated by Tukey's multiple comparison test. All statistical analyses were performed on GraphPad statistical software version 5.0. Results: By comparing the mean of the big ET-1 concentrations of cases and controls, the independent t-test revealed significant higher big ET-1 concentration of OSCC cases when compared to controls $(p<0.0001)$. Tukey's multiple comparison test also revealed statistically significant difference among all OSCC stages in relation to the mean levels of serum big ET-1. However, the mean of the big ET-1 concentrations of cases of grade I and of grade II did not differ statistically $(p=0.729)$. Conclusion: Serum big ET-1 levels may be useful as a diagnostic tool in OSCC and as an adjunct to OSCC staging. However, its use as a prognostic marker warrants larger prospective studies.

Keywords: Endothelin-1. Oral cancer. Cancer staging. Neoplasm grading.

\section{NTRODUCTI ON}

Oral cancer is the $6^{\text {th }}$ most common cancer in the world. India is the highest ranked country in the world with over $1,00,000$ cases per year with mortality rate of $22.9 \%$, which is largely attributed to the late diagnosis of the disease ${ }^{33}$. However, Histopathology remains the gold standard for the diagnose of oral cancer; the grade of differentiation alone shows poor correlation with the outcome and the response to treatment of an individual patient ${ }^{13}$. Also the TNM clinical staging does not provide sufficient predictive information on the optimal treatment beneficial for each patient ${ }^{24}$. This is attributed to the different biological behavior of patients with OSCC with similar clinicopathologic features and results in higher morbidity and mortality rate despite some advances in treatment. Marked prognostic variability exhibited by individual tumors arising from the same site and having identical histological tumor grade warrants additional parameters to classify the tumor 
more precisely in terms of its aggressiveness and biology ${ }^{10}$.

Interest in the role of ET-1 as an angiogenic molecule in cancer has grown over the last two decades, following the demonstration of ET-1 production by several tumor cell lines ${ }^{5,8,14,21}$. The contribution of ET-1 in tumor growth and progression has been evaluated in prostatic, ovarian, renal, pulmonary, colorectal, cervical, breast, lung, bladder, and endometrial cancer ${ }^{1,4,14,17,29-31}$. In the context of oral tissues, it has been demonstrated that keratinocytes can translate and secrete ET-1 protein into the keratinocyte conditioned medium and oral epithelial cell line can produce ET- $1^{34,35}$. ET-1 levels from culture supernatants of human oral SCC cell lines were found to be higher when compared to the one of normal human epidermal keratinocytes ${ }^{6}$. This study also demonstrated that OSCC cells possess the required machinery to synthesize and secrete ET-1. They suggested that ET-1 may act in an autocrine manner on oral SCC cells, promoting their growth, and in paracrine manner on endothelial cells and oral fibroblasts assisting tumor growth and invasion ${ }^{6}$. Currently there is evidence that ET-1 contributes to carcinogenesis directly through proliferation, resistance to apoptosis, migration, and invasion while indirectly through angiogenesis, Extracellular Matrix (ECM) breakdown and deposition ${ }^{14,19}$. Thus, the ET-1 presents itself as a promising biomarker in OSCC. Therefore, this study was designed to assess the use of serum big ET-1 as a biomarker of oral SCC, correlating it with clinical staging and histopathological grading.

\section{MATERI AL AND METHODS}

This study was approved by the Institutional Ethics Committee, including a total of 80 subjects and being composed of a study group of 40 patients histopathologically diagnosed with Oral Squamous Cell Carcinoma (OSCC) and a control group of age 40 and with healthy and sex matched subjects. Patients who had received or were receiving any treatment for carcinoma and patients with known systemic illness or with any other oral disease were excluded from the study. Demographic and clinical features of OSCC cases have been given in Table 1. Informed consent was obtained from all patients and control participants.

The diagnosis of squamous cell carcinoma was confirmed in each case by the histopathological examination of an incisional biopsy in the representative site of the lesion. The relevant history of each patient was done and recorded through clinical examination to rule out any systemic illness or any other local disease or prior therapy. Clinical staging of patients with oral squamous cell carcinoma was performed according to the TNM classification given by the American Joint Committee on Cancer (AJCC) for Staging Atlas ${ }^{15}$ (2006) and End Results Reporting ${ }^{13}$. The histopathological grading of oral squamous cell carcinoma was performed according to the malignancy grading system proposed by Anneroth, et al. ${ }^{2}$ (1987). This grading system is consisted of six parameters: degree of keratinization, nuclear polymorphism, number of mitoses per high power field, pattern of invasion, stage of invasion, and lympho-plasmacytic infiltration. Each parameter was graded from 1 to 4 points. As recommended by Araújo, et al. ${ }^{3}$ (1997), the parameter "stage of invasion" was omitted as incisional biopsy was used for histopathological grading of OSCC. Total scores for malignancy histological grading were obtained by the sum of the scores given for each parameter, and then divided by the number of parameters used. The final grading was done as follows: 1.0 to 2.0 - Grade I; 2.1 to 3.0 - Grade II, and 3.1 to 4.0 - Grade III.

From each subject, $5 \mathrm{ml}$ of intravenous blood was collected using an evacuated blood collection system (Becton, Dickinson and Company, Franklin Lakes, New Jersey, USA). Then, the blood was allowed to clot at room temperature for about 2 hours and then centrifuged at 3000 RPM for 10 minutes to separate the serum for the study. The concentrations of serum big ET-1 were estimated in both cases and controls by the solid phase sandwich ELISA (Immuno-Biological Laboratories Co. Ltd., Fujioka-Shi, Gunma, Japan).

\section{Statistical analysis}

The mean levels of serum big ET-1 among the study and the control group was compared by the independent t-test. The ANOVA test and independent t-test were applied respectively to compare clinical stages and histopathological grades of OSCC cases in relation to their mean levels of serum big ET-1. The significance of the difference between the means of groups was evaluated by Tukey's multiple comparison test. All statistical analyses were performed using GraphPad Prism v.5.0 software. All p-values of $<0.05$ were considered statistically significant.

\section{RESULTS}

The age of the cases and controls of OSCC ranged from 27-72 years and from 25-74 years, respectively, with mean $( \pm S D)$ values of $54.68 \pm 12.95$ years and $53.7 \pm 13.17$ years, respectively. The peak incidence of oral squamous cell carcinoma was noted in the $7^{\text {th }}$ decade of life among the cases OSCC. However, in sex-wise distribution, peak incidence was seen in the $7^{\text {th }}$ decade of life in females, while it was equal 
Table 1- Comparison of clinico pathologic variables of OSCC cases with serum big ET-1 levels

\begin{tabular}{|c|c|c|c|c|}
\hline $\begin{array}{c}\text { Clinicopathologic } \\
\text { variables }\end{array}$ & No. of patients & $\begin{array}{c}\text { Mean serum big } \\
\text { ET-1 levels in } \mathrm{pg} / \mathrm{ml} \\
\text { (Mean } \pm \mathrm{SD})\end{array}$ & Value of $p$ & Significance \\
\hline \multicolumn{5}{|l|}{ Age } \\
\hline $21-30$ & $2(5 \%)$ & $4.23 \pm 1.01$ & 0.6064 & not significant \\
\hline $31-40$ & $7(18 \%)$ & $4.41 \pm 0.62$ & & \\
\hline $41-50$ & $9(22.5 \%)$ & $4.35 \pm 0.53$ & & \\
\hline $51-60$ & 5 (12.5\%) & $4.08 \pm 0.26$ & & \\
\hline $61-70$ & $14(35 \%)$ & $4.76 \pm 0.92$ & & \\
\hline $71-80$ & $3(7 \%)$ & $4.50 \pm 1.37$ & & \\
\hline \multicolumn{5}{|l|}{ Gender } \\
\hline Male & $26(65 \%)$ & $4.35 \pm 0.80$ & 0.1734 & not significant \\
\hline Female & $14(35 \%)$ & $4.70 \pm 0.68$ & & \\
\hline \multicolumn{5}{|l|}{ Anatomic Site } \\
\hline Alveolar mucosa & $13(32.5 \%)$ & $4.35 \pm 0.82$ & 0.063 & not significant \\
\hline Buccal mucosa & $8(20 \%)$ & $4.83 \pm 0.65$ & & \\
\hline Tongue & $6(15 \%)$ & $3.81 \pm 0.54$ & & \\
\hline GB complex & $6(15 \%)$ & $4.85 \pm 0.58$ & & \\
\hline Palate & $2(5 \%)$ & $4.74 \pm 0.62$ & & \\
\hline Multifocal & $2(5 \%)$ & $5.12 \pm 0.49$ & & \\
\hline \multicolumn{5}{|l|}{ Clinical Staging } \\
\hline Stage I & $3(7.5 \%)$ & $2.81 \pm 0.23$ & $<0.001$ & highly significant \\
\hline Stage II & 7 (17.5\%) & $3.72 \pm 0.22$ & & \\
\hline Stage III & $13(32.5 \%)$ & $4.47 \pm 0.40$ & & \\
\hline Stage IV & $17(42.5 \%)$ & $5.07 \pm 0.40$ & & \\
\hline \multicolumn{5}{|l|}{$\begin{array}{l}\text { Histopathological } \\
\text { Grading }\end{array}$} \\
\hline Grade I & $36(90 \%)$ & $4.40 \pm 0.77$ & 0.727 & not significant \\
\hline Grade II & $4(10 \%)$ & $5.12 \pm 0.18$ & & \\
\hline
\end{tabular}

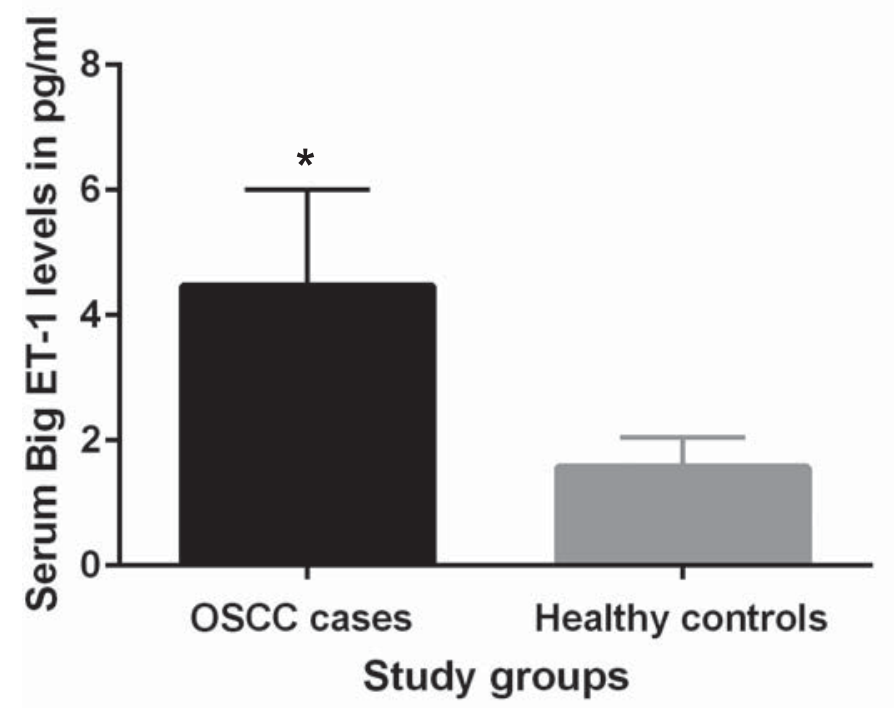

OSCC cases Healthy controls

Figure 1- Comparison of mean levels of big ET-1 between oral squamous cell carcinoma (OSCC) cases and controls using independent t-test. * means $\mathrm{p}<0.0001$ in comparison with healthy controls 
years and the remaining $29(72.5 \%)$ were above 45 years. Male: female ratio of the OSCC cases was 1.8:1.There was no significant difference among groups of different age $(p=0.6064)$ and gender $(p=0.1734)$ in relation to the serum big ET-1 values analyzed by the ANOVA test and the independent t-test, respectively (Table 1 ). The alveolar mucosa was the most common site $(32.5 \%)$ to be involved in patients with OSCC, followed by the buccal mucosa $(20.0 \%)$, the tongue $(15.0 \%)$, and the gingivobuccal complex (15.0\%). Comparing the mean of the big ET-1 concentration between the sites, ANOVA revealed no significant difference $(p=0.063)$ (Table 1$)$. The mean big ET-1 level in multifocal lesions and in the gingivobuccal complex were the highest, the lowest being the mean for tongue.

Comparing the mean big ET-1 concentrations of the two groups, the independent t-test revealed a significantly higher big ET-1 concentration in OSCC cases when compared to controls ( $p<0.0001$, $t=11.37$ ) (Figure 1). Furthermore, intragroup comparison of the mean levels of serum big ET-1 by Tukey's multiple comparison test also revealed statistically significant difference among all OSCC stages (Figure 2). However, the mean of big ET-1 concentrations of cases of grade I of OSCC and of OSCC grade II did not differ statistically $(p=0.729)$ (Figure 3).

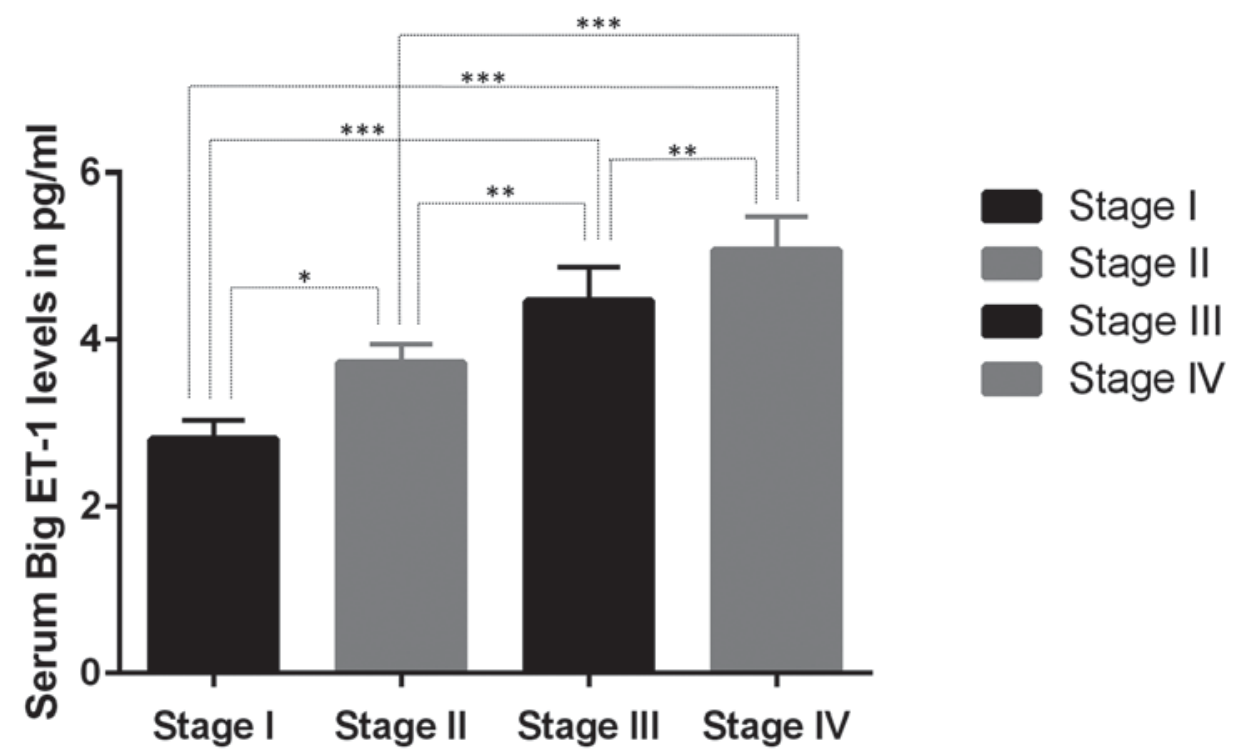

Figure 2- Intergroup and intragroup comparison of mean levels of big ET-1 among clinical stages of oral squamous cell carcinoma (OSCC) cases using one way ANOVA test and Tukey's multiple comparison test respectively $\left({ }^{*} p<0.05\right.$; ${ }^{* *} p<0.01 ;$ and $\left.{ }^{* * *} p<0.001\right)$
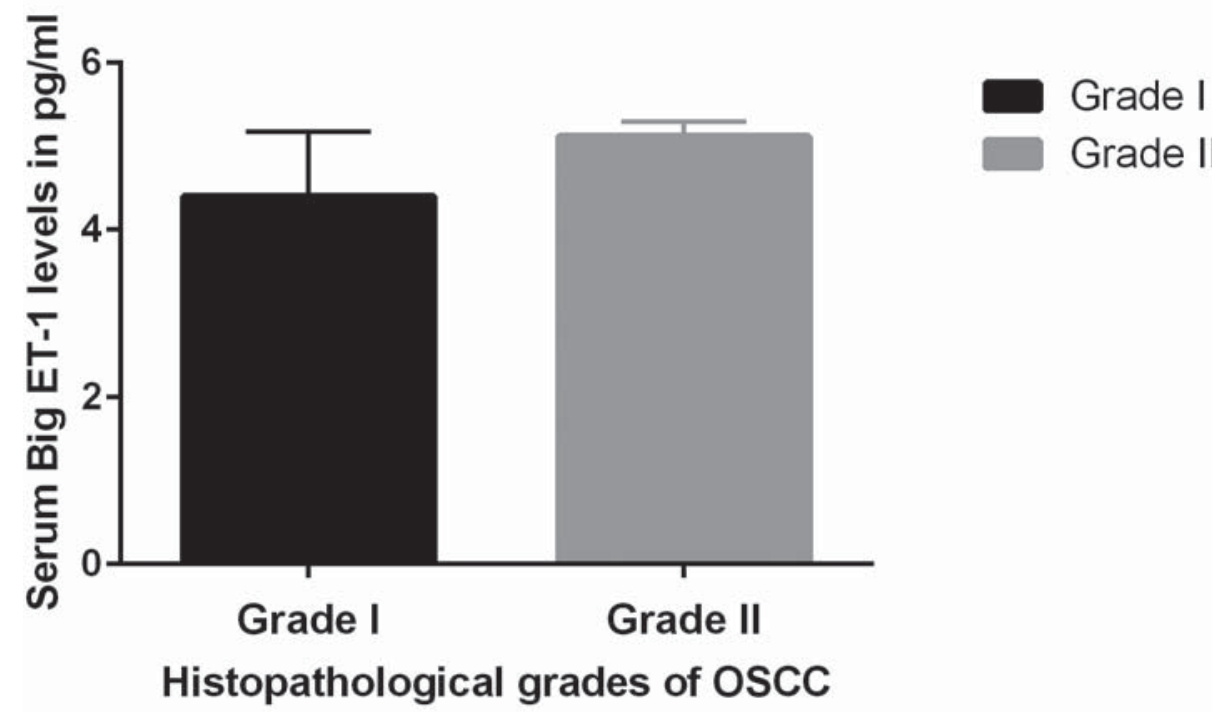

Grade II

Figure 3- Comparison of mean levels of big ET-1 among histopathological grades of oral squamous cell carcinoma (OSCC) cases using independent t-test 


\section{SCUSSION}

Oral cavity cancer is predominantly a disease of middle-aged men as nearly $95 \%$ of carcinomas occur after the age of $45^{33}$. In the present study, the age of the OSCC patients ranged from $27-72$ years with a mean value of $54.68 \pm 12.95$ years. Peak incidence was seen in the $7^{\text {th }}$ decade of life. Similar trend was observed in the studies of Bhurgri, et al. ${ }^{9}$ (2006) with a peak incidence of oral cancer in the $7^{\text {th }}$ decade of life. Although the risk of developing cancer increases with age, in recent years, the incidence of oral cancer have increased in younger ages $^{11}$. In the present study, similar trend was seen in 11 out of $40(27.5 \%)$ patients that were below or equal to 45 years ( 4 of them being females and 7 males). Also 9 out of 11 such patients were in stage III+IV, being correlated with the aggressive presentation at the time of the report. Which is in accordance with previous studies in which younger patients were seen as holders of the disease in its advanced stage ${ }^{22}$.

The endothelin axis (endothelins and their receptors) performs key physiological functions in normal tissue, which includes the modulation of the vasomotor tone, tissue differentiation, development, cell proliferation and hormone production ${ }^{26}$. Endothelin-1 (ET-1) is a predominant and the most relevant biologically isoform among endothelins ${ }^{7}$. The mature endothelin-1 peptide and the $2.5 \mathrm{kDa}$ protein are generated by a cascade of enzymatic cleavage of the initial preproendothelin-1 gene product through stages of proendothelin-1 and big endothelin-1 (big ET-1) 27 . The ET-1 has short plasma half-life (about 1.5 minutes) and low circulating levels which difficult the measurement in plasma or serum ${ }^{23}$. So circulating levels of plasma or serum big ET-1 (precursor) being a stable peptide with plasma half life of 30 minutes may serve as a sensitive indicator of endothelin system activation $^{23}$. The ET-1 levels can be measured in different body fluids like human plasma, saliva, cerebro-spinal fluid, urine, pericardial fluid, breast milk, and amniotic fluid even if the levels vary ${ }^{25}$. Although salivary levels of ET-1 were reported as higher than serum levels in oral cancer, it failed to show positive correlation with disease activity ${ }^{16,28}$.

Epithelially derived tumors exhibit heterogeneity in expression of endothelin-1 receptors ${ }^{8}$. The $\mathrm{ET}_{\mathrm{A}} \mathrm{R}$ dominant cancer (e.g. prostate and ovarian cancer), the $\mathrm{ET}_{\mathrm{B}} \mathrm{R}$ dominant cancer (e.g. melanoma) or the $E T_{A} R$ and the $E T_{B} R$ double receptor cancer (e.g. colon and lung cancer) are three categories that are according to the expression of endothelin receptors in cancer ${ }^{26}$. Cells of OSCC express both $E T_{A} R$ and $E T_{B} R$, which is identical to cells of lung and colon cancer ${ }^{6}$. Those cancers that up-regulate $E T_{A} R$, probably using $E T-1$ as a direct growth factor for cancer cells while those that up-regulate $\mathrm{ET}_{\mathrm{B}} \mathrm{R}$ and probably use ET-1 predominantly as an activator of cells associated to tumor, such as fibroblasts, endothelial cells, and macrophages ${ }^{8,20}$. The up-regulation of $\mathrm{ET}_{\mathrm{A}}$ receptors by ET- 1 in OSCC implicate ET-1 as a growth factor for tumor cells and suggests its role right from tumor initiation ${ }^{6,19}$. These findings present serum endothelin-1 as a promising biomarker for OSCC.

On the assessment of the levels of serum big ET- 1 in cases and controls of OSCC, the mean of the serum level of big ET- 1 was found to be $4.47 \pm 1.54$ $\mathrm{pg} / \mathrm{ml}$ and $1.57 \pm 0.48 \mathrm{pg} / \mathrm{ml}$ respectively. The mean big ET-1 level was significantly higher $(p<0.0001)$ in the cases of OSCC compared to that in the control group. Elevated levels of serum big ET-1have been noted in various nonmalignant and malignant diseases ${ }^{7}$. However, patients in the present study did not have any other systemic disease and were age and sex matched with controls. Thus, the increased level of serum big ET-1 may be attributed to the oral malignant process. Similarly elevated serum/plasma big ET-1 levels were found in hepatocellular carcinoma, primary colon cancer, basal cell carcinoma, nonsmall cell lung cancer, nasopharyngeal carcinoma and esophageal cancer patients in comparison to healthy individuals $\mathrm{s}^{4,5,17,18,23,32}$. Some studies also indicated a decrease in serum or plasma levels of big ET-1 after tumor resection, attributing the increased levels to tumor load ${ }^{18,31}$.

The trend in the mean of the big ET- 1 concentrations among OSCC stages implied progressively increasing levels. By comparing it, ANOVA revealed a significantly different mean of the big ET-1 concentrations among OSCC stages (Table 1, Figure 2). These findings are in accordance with previous studies, in which serum levels of ET-1 are correlated with clinical stages of colorectal adenocarcinoma, esophageal cancer, and colon cancer ${ }^{1,18,29}$. However, one study failed to show significant associations between the plasma big ET-1 level in the advanced stage of nasopharyngeal carcinoma cases and in the overall stage of cancer ${ }^{23}$.

While comparing the levels serum big ET-1 among histopathological grades, levels increased with the histopathological grade of the disease. But the difference in the mean levels of serum big ET-1 between cases of grade I of OSCC and of grade II of OSCC was not statistically significant $(p=0.727)$ (Table 1, Figure 3). Positive correlation found between ET-1 expression and poor histological differentiation or grade in breast cancer and colon cancer is in accordance with these results ${ }^{1,30}$. However, one study reported lack of correlation between plasma levels of big ET-1 and the degree of histologic differentiation in esophageal cancer ${ }^{18}$. 


\section{CONCLUSI ON}

By exploring the presence of biomarkers those do not require the tumor tissue to detect them, but are secreted by cancer cells into the blood stream will not only facilitate an easy detection, but will also be a candidate for population based screening. In accordance with this, the levels of serum big ET-1 can be used as an adjunctive serological marker for the diagnosis of OSCC and may provide further help in prognostic information and disease monitoring. However, prospective studies on a larger sample are needed to substantiate our findings before firm conclusions on the utility of these markers be drawn in the diagnosis and prognostic assessment of oral cancers.

\section{REFERENCES}

1- Abdel-Gawad IA, Hassanein HM, Bahgat NA, Abdel Sattar MA, El-Sissy AH, Altaweel MA, et al. Study of endothelin-1 and vascular endothelial growth factor in patients with cancer colon. J Egypt Natl Canc Inst. 2008;20:216-23.

2- Anneroth G, Batsakis J, Luna M. Review of the literature and a recommended system of malignancy grading in oral squamous cell carcinomas. Scand J Dent Res. 1987;95:229-49.

3- Araújo VC, Loyola AM, Pinto Júnior DD, Borra RC, De Araújo NS. p53 in biopsies of oral squamous cell carcinoma. A comparative study with a malignancy grading system. Oral Oncol. 1997;33:5-9. 4- Arun C, DeCatris M, Hemingway DM, London NJ, O'Byrne KJ. Endothelin-1 is a novel prognostic factor in non-small cell lung cancer. Int J Biol Markers. 2004;19:262-7.

5- Asham EH, Loizidou M, Taylor I. Endothelin-1 and tumor development. Eur J Surg Oncol. 1998;24:57-73.

6- Awano S, Dawson LA, Hunter AR, Turner AJ, Usmani BA. Endothelin system in oral squamous carcinoma cells: specific siRNA targeting of ECE-1 blocks cell proliferation. Int J Cancer. 2006;118:1645-52.

7- Barton M, Yanagisawa M. Endothelin: 20 years from discovery to therapy. Can J Physiol Pharmacol. 2008;86:485-98.

8- Bhalla A, Haque S, Taylor I, Winslet M, Loizidou M. Endothelin receptor antagonism and cancer. Eur J Clin Invest. 2009;39:74-7. 9- Bhurgri Y, Bhurgri A, Usman A, Pervez S, Kayani N, Bashir I, et al. Epidemiological review of head and neck cancers in Karachi. Asian Pac J Cancer Prev. 2006; 7:195-200.

10- Chimenos-Kustner E, Font-Costa I, López-López J. Oral cancer risk and molecular markers. Med Oral Patol Oral Cir Bucal. 2004;9:377-80.

11- Chitapanaraux I, Lorvidhaya V, Sittitrai P, Pattarasakulchai $T$, Tharavichitkul $E$, Sriuthaisiriwong $P$, et al. Oral cavity cancers at a young age: analysis of patient, tumor and treatment characteristics in Chiang Mai University Hospital. Oral Oncol. 2006;42:83-8.

12- Dissanayaka WL, Pityage G, Kumarasiri PV, Liyanage RL, Dias KD, Tilakaratne WM. Clinical and histopathologic parameters in survival of oral squamous cell carcinoma. Oral Surg Oral Med Oral Pathol Oral Radiol. 2012;113:518-25.

13- Edge SB, Byrd DR, Compton CC, Fritz AG, Greene FL, Trotti A. AJCC Cancer staging manual. $7^{\text {th }}$ ed. New York: Springer; 2010. 14- Grant K, Loizidou M, Taylor I. Endothelin-1: a multifunctional molecule in cancer. $\mathrm{Br}$ J Cancer. 2003;88:163-6.

15- Greene FL, Compton CC, Fritz AG, Shah JP, Winchester DP. Lip and oral cavity. In: AJCC cancer staging atlas. $6^{\text {th }}$ ed. New York: Springer; 2006. p. 19-26.
16- Hoffman RR, Yurgel LS, Campos MM. Evaluation of salivary endothelin-1 levels in oral squamous cell carcinoma and oral leukoplakia. Regul Pept. 2011;166:55-8.

17- Ishibashi M, Fujita M, Nagai K, Kako M, Furue H, Haku E, et al. Production and secretion of endothelin by hepatocellular carcinoma. J Clin Endocrinol Metab. 1993;76:378-83.

18- Jiao WJ, Xu J, Zheng J, Shen Y, Lin L, Li J. Elevation of circulating big endothelin-1: an independent prognostic factor for tumor recurrence and survival in patients with esophageal squamous cell carcinoma. BMC Cancer. 2008;8:334-8.

19- Knowles J, Loizidou M, Taylor I. Endothelin-1 and angiogenesis in cancer. Curr Vasc Pharmacol. 2005;3:309-14.

20- Knowles JP, Shi-Wen X, Haque S, Bhalla A, Dashwood M, Yang $S$, et al. Endothelin-1 stimulates colon cancer adjacent fibroblasts. Int J Cancer. 2012;130:1264-72.

21- Kusuhara M, Yamaguchi K, Nagasaki K, Hayashi C, Suzaki A, Hori $S$, et al. Production of endothelin in human cancer cell lines. Cancer Res. 1990;50:3257-61.

22- Llewellyn CD, Johnson NW, Warnakulasuriya S. Risk factors for squamous cell carcinoma of the oral cavity in young people - a comprehensive literature review. Oral Oncol. 2001;37:401-18.

23- Mai HQ, Zeng ZY, Zhang CQ, Feng KT, Guo X, Mo HY, et al. Elevated plasma Big ET-1 is associated with distant failure in patients with advanced-stage nasopharyngeal carcinoma. Cancer. 2006;106:1548-53.

24- Massano J, Regateiro FS, Januário G, Ferreira A. Oral squamous cell carcinoma: a review of prognostic and predictive factors. Oral Surg Oral Med Oral Pathol Oral Radiol Endod. 2006;102:67-76. 25- Mori M, Namba M, Muramatsu Y, Sumitomo S, Takai Y, Shikimori M. Endothelin expression in salivary gland. Oral Science International. 2011;8:7-10.

26- Nelson J, Bagnato A, Battistini B, Nisen P. The endothelin axis: emerging role in cancer. Nat Rev Cancer. 2003;3:110-6.

27- Peto H, Corder R, Janes RW, Wallace BA. A molecular model for human Big-Endothelin-1 (Big ET-1). FEBS Lett. 1996;394:191-5. 28- Pickering $\mathrm{V}$, Jordan RC, Schmidt BL. Elevated salivary endothelin levels in oral cancer patients - a pilot study. Oral Oncol. 2007;43:37-41.

29- Simpson RA, Dickinson T, Porter KE, London NJ, Hemingway DM. Raised levels of plasma big endothelin 1 patients with colorectal cancer. Br J Surg. 2000;87:1409-13.

30- Smollich M, Götte M, Yip GW, Yong ES, Kersting C, Fischgräbe J, et al. On the role of endothelin-converting enzyme-1 (ECE-1) and neprilysin in human breast cancer. Breast Cancer Res Treat. 2007;106:361-9.

31- Teng XJ, Shen ZX, Xiang JJ, Shen L, Yuan L, Guo J, et al. Pre- and post-operative plasma big endothelin-1 levels in patients with gastric carcinoma undergoing radical gastrectomy. Anticancer Res. 2006;26:2503-8.

32- Vural P, Erzengin D, Canbaz M, Selçuki D. Nitric oxide and endothelin-1,2 in actinic keratosis and basal cell carcinoma: changes in nitric oxide/endothelin ratio. Int J Dermatol. 2001;40:704-8.

33- Warnakulasuriya S. Global epidemiology of oral and oropharyngeal cancer. Oral Oncol. 2009;45:309-16.

34- Yamamoto E, Awano S, Koseki T, Ansai T, Takehara T. Expression of endothelin-1 in gingival epithelial cells. J Periodontal Res. 2003;38:417-21.

35- Yohn JJ, Morelli JG, Walchak SJ, Rundell KB, Norris DA, Zamora MR. Cultured human keratinocytes synthesize and secrete endothelin-1. J Invest Dermatol. 1993;100:23-6. 